Jurnal Konstruksi Hukum | ISSN: XXXX | E-ISSN: XXXX Vol. 1, No. 1, September 2020 Hal. 63-67| Available online at https://www.ejournal.warmadewa.ac.id/index.php/jukonhum DOI: https://doi.org/10.22225/jkh.1.1.2130.63-67

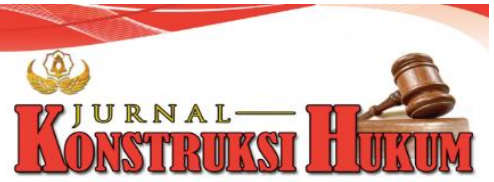

\title{
PERLINDUNGAN HUKUM BAGI PEDAGANG MOBIL BEKAS TERHADAP KONSUMEN YANG MELAKUKAN WANPRESTASI
}

\author{
Bagus Putu Lanang Agastya, Anak Agung Sagung Laksmi Dewi, Ni Made Puspasutari Ujianti \\ Fakultas Hukum Universitas Warmadewa, Denpasar-Bali, Indonesia
}

\begin{abstract}
Abstrak
Jual beli memerlukan keahlian dalam hukum perjanjian mengenai syarat sahnya perjanjian dan segala ketentuan dalam perjanjian hukum perjanjian yang mengatur jalannya kegiatan jual beli dan melindungi para pihak dari pelanggaran hukum wanprestasi mengenai hak dan kewajiban masing masing pihak. Tujuan penelitian ini yatu untuk mengetahui bentuk peraturan perlindungan hukum bagi pedagang mobil bekas terhadap konsumen yang melakukan wanprestasi dan mengetahui akibat hukum bagi konsumen yang melakukan wanprestasi. Penelitian ini menggunakan metode normative. Teknik analisis data dilakukan secara sistematis dengan menggunakan argumentasi hukum dan disajikan dalam bentuk deskriptif. Hasil penelitian menunjukan bahwa unutk melindungi para pihak dari suatu wanprestasi perlu perjanjian yang sifatnya mengikat dan masing masing memiliki hak dan kewajiban jika di langgar akan mendapatkan sanksi sesuai dengan isi perjanjian yang di buat umunya berupa ganti rugi. Sementara itu, akibat adanya wanprestasi yang dilakukan konsumen harus bertanggungjawab dan mengganti rugi sesuai kesepatakan antara kedua belah pihak. Oleh karena itu, melalui penelitian ini diharapkan agar kegiatan perdagangan hendaknya dipahami dan dimengerti pentingnya mengadakan perjanjian dan memperhatikan segala bentuk syarat-syarat dalam hukum perjanjian. Tujuannya untuk melindungi diri sendiri dari kejadian yang tidak di inginkan.
\end{abstract}

Kata Kunci: Perlindungan hukum; Undang-Undang jual beli; Wanprestasi

\begin{abstract}
The sale and purchase of expertise in contract law regarding the terms of the legality of the agreement and all the provisions in the legal agreement governing the sale and purchase activities and protecting the parties from default regarding the rights and obligations of each party. The purpose of this study is to determine the form of legal protection regulations for used car dealers against consumers who default and respond to the law for consumers who default. This study uses a normative method. The data analysis technique was carried out systematically using legal arguments and presented in a descriptive form. The results showed that in order to protect the parties from a default, it is necessary to have an agreement that is binding in nature and each of them has rights and obligations if it is violated, it will set a sanction in accordance with the agreement made in general in the form of compensation. Meanwhile, the result of default by the consumer must be responsible and compensate according to the agreement between the two parties. Therefore, through this research it is hoped that trade activities are carried out and implement the importance of agreements and pay attention to all requirements in the law. The goal is to protect yourself from unwanted events.
\end{abstract}

Keywords: Default; Legal protection; Law of sale and purchase

\section{PENDAHULUAN}

Teknologi dalam segala bidang memberi kemudaha para penggunanya teknologi telah memasuki segala aspek aspek kehidupan manusia di seluruh dunia sebagai kebutuhan tersier salah satunya transportasi atau kendaraan bermotor yang dapat membantu manusia berinteraksi satu sama lain. Didasari Undang-Undang Republik Indonesia Tahun 1945 pada pasal 28c ayat (1) dan ayat (2) menyatakan (1) Setiap orang berhak mengembangkan diri melalui pemenuhan kebutuhan dasarnya berhak mendapat pendidikan dan memperoleh manfaat dari ilmu pengetahuan dan teknologi seni dan budaya demi meningkatkan kualitas hidupnya dan demi kesejahteraan umat manusia. (2) Setiap orang berhak untuk memajukan dirinya dalam memperjuangkan haknya secara kolektif untuk membangun masyarakat bangsa dan negaranya. 
Dengan adanya Undang-Undang yang mengatur serta kemajuan teknologi seperti ini memberikan banyak dampak ke perdagangan Otomotif produsen-produsen teknologi khususnya produsen yang memproduksi kendaraan roda empat atau yang biasa di sebut dengan mobil dari berbagai merk dan type berlomba lomba memberi segala bentuk kemudahan dan kenyamanan dalam fasilitas demi kepuasan terhadap pelanggannya sehingga tak jarang pembeli harus rela menunggu dan memesan beberapa lama terlebih dahulu. Masyarakat modern yang berpindah pindah melakukan aktivitas dari satu tempat ke tempat lainnya mobilitas yang tinggi menyebabkan kendaraan dan masyarakat tidak dapat di pisahkan di tambah dengan kendaraan umum yang belum dapat mengimbangi kebutuhan masyarakat maka kendaraan pribadi menjadi yang di utamakan dalam hal ini dengan kemampuan dan fasilitas yang di dapat yang semakin canggih harga yang di tawarkanpun kian meroket dengan demikian menimbulkan banyak peluang-peluang bisnis bagi para pelaku usaha dagang khususnya Pedagang Mobil Bekas. Perbuatan jual beli biasanya membutuhkan perjanjian tertulis yang terjadi antara kedua belah pihak dengan di tambahkan materai sebagai penguat hukum dan menimbulkan akibat hak dan kewajiban yang harus di taati oleh para pihak.

Pelaku usaha dalam hubungannya dengan pihak lain selalu senantiasa mengharapkan agar perjanjian dapat di tepati namun demikian seiring berjalannya waktu tidak dapat menutup kemungkinan terjadinya konflik hukum antara pihak penjual dan pembeli. Jual beli merupakan bentuk kegiatan tukar menukar atau transaksi umum yang di lakukan dalam masyarakat yang biasanya jual beli di berlakukan oleh orang orang yang ingin melepas hak atau prestasi dan orang yang menginginkan hak atas prestasi biasanya perjanjian jual beli dilakukan secara lisan dan tulisan dimana dimaksudkan untuk memastikan tujuan dalam jual beli dan hukum yang mengatur dalam jual beli di berlakukan. Mengingat harus adanya hukum yang melindungi para pihak.Perlindungan hukum adalah memberikan pengayoman kepada hak asasi manusia yang dirugikan orang lain dan perlindungan tersebut diberikan kepada masyarakat agar mereka dapat menikmati semua hak-hak yang diberikan oleh hukum atau dengan kata lain perlindungan hukum adalah berbagai upaya hukum yang harus diberikan oleh aparat penegak hukum untuk memberikan rasa aman baik secara pikiran maupun fisik dari gangguan dan berbagai ancaman dari pihak manapun (Rahardjo, 2000).

Perikatan adalah suatu perbuatan yang di dasari oleh sebuah hubungan hukum yang mengatur para pihak antara dua orang atau lebih yang ada dan bersangkutan di dalamnya dimana dari perikatan tersebut dapat menjanjikan atas sebuah prestasi yang dimiliki dimana hubungan hukum tersebut melahirkan sebuah hak dan kewajiban bagi salah satu pihak menjadi Undang-Undang bagi mereka yang membuatnya. Pelaksanaan hak dan kewajiban inilah seringkali menimbulkan pelanggaran atau akibat hukum oleh hubungan dalam masyarakat tersebut maka dari itu hukum mengatur hubungan tersebut melalui peraturan sehingga tercapai kepastian hukum dan keseimbangan terkait dengan hak dan kewajiban. Undang-Undang Hukum Perdata yang menyatakan bahwa tiap-tiap perikatan di lahirkan baik karena persetujuan baik karena Undang-Undang. Dimana dengan apa yang di maksudkan setiap orang yang berkeinginan untuk mengikatkan dirinya atas suatu prestasi telah sepakat melakukan perjanjian yang berdasarkan persetujuan baik secara bersama maupun dengan peraturan perundang-undangan. Perikatan berarti dapat di munculkan oleh masyarakat umum perorangan dengan beberapa orang yang telah sepakat menyetujui atas apa yang menjadi prestasi yang di ingin di miliki atau di capainya.dalam perikatan ada perikatan untuk berbuat sesuatu dan untuk tidak berbuat sesuatu. Yang dimaksud dengan perikatan untuk berbuat sesuatu adalah melakukan perbuatan yang sifatnya positif halal tidak melanggar undang-undang dan sesuai dengan perjanjian. Sedangkan perikatan untuk tidak berbuat sesuatu yaitu untuk tidak melakukan perbuatan tertentu yang telah disepakati dalam perjanjian (Muhammad, 2010).

Perjanjian jual beli adalah perjanjian dengan mana penjual memindahkan atau setuju memindahkan hak milik atas barang kepada pembeli sebagai imbalan sejumlah uang yang disebut harga (Muhammad, 2010). Harga tersebut harus berupa sejumlah uang. Jika dalam suatu perjanjian tidak menunjuk kepada dua hal tersebut (barang dan uang) maka itu akan merubah perjanjiannya menjadi tukar menukar atau kalau harga itu berupa jasa perjanjiannya akan menjadi suatu perjanjian kerja dan begitulah seterusnya. Dalam pengertian jual beli sudah termasuk pengertian bahwa disatu pihak ada barang dan dilain pihak ada uang. Tentang macamnya uang dapat diterangkan bahwa meskipun jual beli itu terjadi di Indonesia tidak diharuskan bahwa harga itu ditetapkan dalam mata uang rupiah namun diperbolehkan kepada para pihak untuk menetapkannya dalam mata uang apa saja. 
Pada tahun 2017 Deler Mobil Bekas bernama DD Jaya Auto kronologi dari kasus tersebut dimana ada seorang konsumen yang pada saat itu sepakat untuk membeli sebuah mobil yang berjenis Minibus merk Toyota dengan type Fortuner tahun 2010 berwarna hitam metalik seharga Rp. 225.000.00000. Dimana setelah terjadinya transaksi berupa tanda jadi atau sering di sebut dengan DP guna untuk mengikat antara Pihak Deler dengan Konsumen dengan cara pembayaran bertahap yaitu 4 tahapan kepada Pihak Deler tanpa peran perantara Pihak Ketiga (Finance) yang telah di bayarkan sejumlah Rp.30.000.00000 dengan kebijakan sebelum pembayaran di lunasi hanya kendaraan yang dapat di bawa oleh pembeli tidak dengan surat surat yang berkaitan dengan barang tersebut terkecuali Surat Tanda Nomor Kendaraan (STNK). Selang beberapa hari setelah penyerahan mobil tanpa surat Buku Pemilik Kendaraan Bermotor (BPKB) dilakukan pembeli kembali datang kembali ke Deler untuk meminjam BPKB kendaraan tersebut dengan alasan untuk di pinjamkan uang di sebuah BANK guna melunasi pembayaran yang di tunggaknya di Deler tersebut satu bulan terhitung dari pengambilan BPKB atas dasar rasa kepercayaan dari pihak deler kepada Sipembeli Pihak Deler memberikan BPKB kendaraan tersebut dengan harapan pembayaran dapat di lakukan sesuai perjanjian. Akan tetapi setelah satu bulan terhitung dari pengambilan BPKB tersebut tidak juga ada kejelasan terhadap pembayaran dan Pembeli tidak dapat di hubungi hingga saat ini.

Berikut ini beberapa penelitian sebelumnya telah mengkaji tentang wanprestasi seperti Adati (2018); Dsalimunthe (2017); Prayogo (2016); Ramadhona \& Dharmakusuma (2019); Sudjana (2019); Warmadewa \& Udiana (2017). Dari hasil penelitian tersebut mengatakan bahwa wanprestasi adalah suatu keadaan dan kondisi tidak terpenuhinya sebuah perjanjian atau kesepakatan. Berdasarkan latarbelakang masalah di atas, maka penelitian saat ini bertujuan untuk mengetahui bentuk perlindungan hukum bagi pedagang mobil bekas terhadap konsumen yang melakukan wanprestasi dan mengetahui akibat hukum bagi konsumen yang melakukan wanprestasi.

\section{METODE PENELITIAN}

Penelitian ini didesain dengan menggunakan pendekatan deskriptif kualitatif dengan metode hukum normative. Jenis data yang digunakan dalam penelitian ini bersumber dari bahan hukum primer seperti undang-undang dasar negara Indonesia dan bahan hukum sekunder seperti buku-buku atau literature dan jurnal dan sumber kepustakaan lainnya. Teknik pengumpulan bahan hukum yang di gunakan dalam penelitian ini dengan cara metode pencatatan dengan cara mengumpulkan, menginvestarisasikan dengan pengkutipan terhadap undang-undang, buku-buku serta dokumen yang berkaitan dengan pokok masalah yang ada. Kemudian, data dianalisis dengan menggunakan teknik deskriptif melalui kata-kata dan disajikan dalam paragraf.

\section{HASIL DAN PEMBAHASAN}

Manusia sebagai subjek hukum yang secara alamiah hidup dengan berkelompok atau masyarakat kehidupan manusia tidak akan bisa terlepas dari kebutuhan kebutuhan pokok diantaranya sandang pangan dan papan untuk memperoleh itu semua manusia membutuhkan satu sama lain sebagai pelengkap dimana ada yang menjual di sebut penjual dan ada yang membeli di sebut konsumen dalam tindakan tersebut timbulah suatu perbuatan hukum yang bersifat mengikat satu sama lain sebagaimana tujuan yang mereka inginkan yang di sebut perjanjian dimana perjanjian mengatur tentang hak dan kewajiban dari para pihak selaku penjual dan pembeli dimana penjual memiliki hak untuk mendapatkan sebuah imbalan atau harga dan memiliki kewajiban menyerahkan suatu barang atau prestasi yang dimilikinya sedangkan pembeli memiliki hak untuk mendapatkan barang yang di inginkan dan memiliki kewajiban membayar barang sesuai harga yang di sepakati. Membuat suatu perjanjian haruslah sesuai dengan prosedur-prosedur yang telah di tetapkan dan telah di landasi pada suatu kesepakatan tanpa paksaan dari masing masing pihak yang murni dari keinginan dan kemauan mereka tersendiri bukan karena adanya suatu keinginan atau kehendak yang bersifat memaksa sesuai dengan peraturan pemerintah berkaitan dengan hykum perdata dimana untuk sahnya perjanjian di perlukan 4 syarat:

1. Sepakat mereka yang mengikatkan dirinya

Berarti para pihak telah mengetahui bentuk dan isi dari perjanjian yang mereka buat dan dengan itu setuju untuk membuat suatu kesepakatan yang menimbulkan akibat hukum.

2. Kecakapan untuk membuat suatu perikatan.Dimana para pihak telah di anggap mampu dan dapat berpikir dewasa untuk memahami isi dan bentuk-bentuk perjanjian yang mereka setujui. 
3. Suatu hal tertentu

Mengetahui bahwa apa yang mereka sepakati serupakan suatu prestasi yang di inginkan untuk di di serahkan oleh pemilik selaku penjual dan di terima sebagaimana yang di inginkan oleh konsumen atau pembeli.

4. Suatu sebab yang halal

Dengan berdasarkan kemampuan untuk melepas suatu prestasi yang di peroleh bukan dari tindakan yang melanggar ketentuan hukum yang di atur dalam perundang-undangan.

Atas dasar kepercayaan salah satu pihak melakukan tindakan yang tidak sejalan dengan di buatnya perjanjian tersebut berupa tidak melakukan kewajiban yang semestinya di bayarkan sesuai perjanjian kepada penjual sehingga konsumen dapat di katakan melakukan wanprestasi atau ingkar janji dan melanggar suatu asas asas hukum perjanjian yang terdapat pada pasal 1338 ayat (3) Kitab UndangUndang Hukum Perdata yang menyatakan bahwa "suatu perjanjian harus dilaksanakan dengan itikad baik". Wanprestasi ialah tidak memenuhi atau lalai dalam melaksanakan kewajiban sebagaimana yang ditentukan dalam perjanjian yang di buat antara kreditur dengan debitur wanprestasi dapat berupa perbuatan

- Sama sekali tidak memenuhi prestasi.

- Prestasi yang dilakukan tidak sempurna.

- Terlambat memenuhi prestasi.

- Melakukan apa yang dalam perjanjian dilarang untuk dilakukan (Miru, 2007).

Kesengajaan ataupun lalai kedua hal tersebut mengakibatkan akibat hukum yang berbeda dimana bila kesengajaan terjadi berarti pihak dengan sadar melakukan sesuatu atau perbuatan melanggar hukum dengan resiko yang lebih berat sedangkan lalai berarti pihak secara tidak sadar telah melakukan tindakan wanprestasi atau melanggar hukum dan resiko yang dapat di maklumi.mengenai konsumen yang melakukan wanprestasi pedagang akan mengirimkan surat peringatan yang menyatakan diamana konsumen telah melakukan wanprestasi dengan somasi bahwa konsumen telah tidak melakukan kewajibannya sebagai pembeli. Prof. Subekti wanprestasi adalah suatu tindakan dimana si berutang (debitur) tidak melakukan apa yang dijanjikannya dalam perjanjian atau melanggar perjanjian dengan melakukan apa yang tidak boleh dilakukannya atau bisa dikatakan bahwa si debitur alpa lalai atau ingkar janji (Subekti, 2001).

Pelaksanaan suatu perjanjian membawa konsekuensi bahwa seluruh harta kekayaan seseorang atau badan yang diakui sebagai badan hukum, akan dipertaruhkan dan dijadikan jaminan atas setiap perikatan atau kontrak orang perorangan dan atau badan hukum tersebut, sebagaimana yang dijelaskan dalam Pasal 1131 KUH Perdata (Widjaja \& Muljadi, 2003). Dari ketentuan tersebut di atas dengan didasari dengan asas itikad baik yang tidak diberlakukan sehingga menyebabkan kerugian bagi salah satu pihak maka konsumen dapat dikatakan wanprestasi dan mendapat konsekuensi atas tindakannya berupa ganti rugi di antaranya biaya, rugi, dan bunga.

\section{SIMPULAN DAN SARAN}

\section{Simpulan}

Menjalankan usaha perdagangan merupakan kegiatan individu atau kelompok mencari keuntungan untuk memenuhi kebutuhan hidup sehari-hari dengan mengupayakan menyediakan barang atau jasa yang dapat di jadikan sebuah transaksi tukar menukar. Pasal 1338 KUHPerdata ayat 3 yaitu itikad baik menjadi dasar hukum bagi pedagang. Pedagang membutuhkan konsumen sebagai pembeli atau penerima jasa yang disediakan oleh pedang, bertemunya pedagang dan konsumen memiliki sebuah ikatan disebut perjanjian yang bertujuan untuk mengatur para pihak dalam bertransaksi sebagaimana yang diperlukan untuk mencegah terjadinya suatu tindakan melanggar hukum.

Perjanjian suatu ikatan atau kesepakatan para pihak atas prestasi yang dimiliki tentu memiliki sebuah nilai khusus di dalamnya jalannya perjanjian yang melibatkan banyak pihak tentu kemungkinan akan terjadinya tindakan hukum dalam hukum perjanjian disebut Wanprestasi. Untuk melindungi para pihak dari suatu wanprestasi perlu perjanjian yang sifatnya mengikat dan masing masing memiliki hak dan kewajiban jika di langgar akan mendapatkan sanksi sesuai dengan isi perjanjian yang di buat umunya berupa ganti rugi. 


\section{Saran}

Melalui penelitian ini diharapkan agar kegiatan perdagangan hendaknya dipahami dan dimengerti pentingnya mengadakan perjanjian dan memperhatikan segala bentuk syarat-syarat dalam hukum perjanjian. Tujuannya untuk melindungi diri sendiri dari kejadian yang tidak di inginkan. Kegiatan berdagang tidak cukup dengan memberi rasa kepercayaan pada konsumen untuk memberikan sebuah prestasi atau barang. Namun, perlu perjanjian yang mengikat. Artinya, ada hak dan kewajiban pada masing-masing pihaknya dan memiliki kesadaran untuk tidak melakukan wanprestasi atau melanggar asas itikad baik pada pasal 1338 ayat 3 Kitab Undang-Undang Hukum Perdata.

\section{DAFTAR PUSTAKA}

Adati, M. A. (2018). Wanprestasi dalam Perjanjian yang Dapat Dipidana menurut Pasal 378 Kitab Undang-Undang Hukum Pidana. Lex Privatum, 6(4), 5-15.

Dsalimunthe, D. (2017). Akibat Hukum Wanprestasi Dalam Perspektif Kitab Undang-Undang Hukum Perdata (BW). Jurnal Al-Maqasid, 3(1), 12-29.

Miru, A. (2007). Hukum Kontrak dan Perancangan Kontrak. Jakarta: Rajawali Pers.

Muhammad, A. (2010). Hukum Perjanjian. Bandung: PT Alumni.

Prayogo, S. (2016). Penerapan Batas-Batas Wanprestasi Dan Perbuatan Melawan Hukum Dalam Perjanjian. Jurnal Pembaharuan Hukum, 3(2), 280-287.

Rahardjo, S. (2000). Ilmu Hukum. Bandung: Citra Aditya Bakti.

Ramadhona, B. C., \& Dharmakusuma, A. A. G. A. (2019). Perlindungan Hukum Terhadap Konsumen Akibat Wanprestasi Penjual Dalam Transaksi Elektronik. Kertha Semaya, 2(4), 1-15.

Subekti. (2001). Pokok-Pokok Hukum Perdata (Cetakan 15). Jakarta: PT. Intermasa.

Sudjana. (2019). Akibat Hukum Wanprestasi dan Tanggung Jawab Para Pihak dalam Transaksi Anjak Piutang. Veritas et Justitia, 5(2), 374-398.

Warmadewa, I. M. A., \& Udiana, I. M. (2017). Akibat Hukum Wanprestasi dalam Perjanjian Baku. Kertha Semaya, 5(2), 1-6.

Widjaja, G., \& Muljadi, K. (2003). Perikatan yang Lahir dari Undang-Undang. Jakarta: PT. Raja Grafindo Persada. 